\title{
Construction of Evaluation Index System for Complex Product Engineering Change Scheme
}

\author{
Gao Sheng Han ${ }^{1, a}$, Su Xiang ${ }^{1}$, Wang Zhi Ying ${ }^{1}$ \\ ${ }^{1}$ School of Economics and Management, Jiangsu University of Science and Technology, Zhenjiang, \\ Jiangsu,China \\ aemail:gaosh5289@163.com
}

Keywords: Index system, Scheme evaluation, Engineering change, Decision basis

\begin{abstract}
Evaluation and optimization of complex product engineering change schemes are the key links in the design and manufacturing process. In this link, it is crucial to construct a reasonable index system of engineering change scheme evaluation. This paper constructs a two-layer index system of six levels including quality, finance, period, technology, safety and environment, subdividing into fifteen sub-items through literature combing and considering the objective constraints of engineering change. The result provides support basis for the evaluation and optimization of complex product engineering change scheme instead of expert experience, and significantly improve the economy, efficiency and quality of engineering changes.
\end{abstract}

\section{Introduction}

Complex product is designed and manufactured with long-term, complex, dynamic and other characteristics, and a large number of uncertain factors exist in the manufacturing process, resulting in engineering changes[1].At present, engineering change has become a normalization of the problem in complex product design and manufacturing. Due to multi-factor that constraints engineering changes and multi-subject that designs changing schemes and other reasons, a number of viable alternative engineering change schemes are often produced in this stage. Unreasonable engineering change scheme will cause the adjustment of the production plan and bring a series of changes in risk such as inventory scrapped, construction period delayed. And the excellent engineering change schemes can not only greatly reduce the possible cost of the change and the duration of the risk, but also can go beyond the initial program. Therefore, making scientific evaluation for engineering change schemes could further improve the level of scientific management of manufacturing enterprises.

The evaluation of schemes need identify the key factors that affect the merits and demerits of the engineering change schemes, it also means the construction of the indicator system is the key to evaluate the complex product engineering change schemes. This will not only optimize a single solution, but also to lay the foundation for scheme optimization. At present, the research on the product scheme is focused on the conceptual design stage, which rarely involves the engineering scheme of the engineering change stage. Fang[2] et al proposed a product design scheme evaluation model based on rough set and uncertain multi-attribute decision making method. Sa[3] put forward the decision model of complex product scheme based on VIKOR considering the definition of the weight of experts. Zeitoun and Oberlende[4] indicate that the factors that may affect the change can be identified before the project changes, depending on the project conditions, to achieve the design. Gong[5] et al. Used the design structure matrix and graph theory to study the influence degree of Hub node on engineering change, and proposed to study engineering change from Hub node. Most of the existing literature focused on the impact of engineering changes, while the indicators of multi-scheme optimization problem are less involved in the system of complex product engineering change. Based on the above problems, this paper combines previous research, establishing a index system of engineering change scheme evaluation to make up for the lack of the complex product engineering change schemes without comprehensive indicators to optimize for. 


\section{Index system construction}

\subsection{Basis of construction}

The merits and demerits of the engineering changes are determined by the degree which they can achieve their product objectives in the future. It can determine the evaluation indicators of engineering change schemes according to the complex product manufacturing objectives. At the same time, the index system also need meet the requirement that the level of index is diversified and the choice of indicators should be comparable and independent.

\subsection{Analysis Index system construction}

Based on the index system of conceptual design evaluation and the relevant research of scheme evaluation, this paper divides the factors that evaluate the merits and demerits of the change schemes into the following six levels.

1. Quality level: It is one of the goals of complex product engineering change to guarantee and enhance product quality, so the product quality involved in the scheme is an essential factor in evaluating engineering change scheme. Simon[6] According to the definition of complex products by Simon, a single engineering change may lead to a series of chain reactions because of the complex structure of complex products. Therefore, when evaluating the change scheme, we should not only consider the quality of the engineering change project, but also consider the quality of engineering change propagating project. At the same time, the overall quality is also the key project to be evaluated. Quality impact is generally based on the quality assurance system of the change program, the quality control point setting, the staffing situation and other comprehensive evaluation.

2. Finance level: Low input and high output is the goal of the enterprise to pursue, but also the manufacturing requirements of complex product for manufacturers. In fact, for complex product change manufacturing, the future manufacturing costs and comprehensive benefits and other financial factors will also become a key factor in the evolution of the change schemes. Financial factors mainly take into account the expected cost, expected return and financial risk after the change of the complex product to be planned. Costs include engineering fees, labor costs, taxes, etc. The proceeds mainly refer to the total price of the contract after the change; the financial risk mainly considers the probabilistic risk that may occur after inflation, account arrears and financing difficulties.

3. Period level: The extension caused by the duration of engineering change will lead to a significant reduction in the competitiveness of the product beyond the original schedule. Tian[7] analysis the period risk of naval gun weapon system development, and defined the duration of the delay time as the risk factors of the duration of the delay time of the sum. Qiu[8] established random network progress risk model, obtained to minimize the risk of progress, that is, to avoid the manufacturing process of rework. Scholars consider the schedule as research focus of product development, manufacturing, change, generally speaking, the shortest duration can reduce the loss of time value in the case of technical and financial permission. The total time limit is the time from the date of product contract signed to the time of product delivery.

4. Technology level: The technical complexity of complex products is one of its characteristics. Engineering change often involves technological change, so technical factors should be used as a measure of the evolution of the change scheme. For a change project, whether the technology is advanced and mature and whether the resources could effectively supply requirements will affect the realization and change degree of the complex product engineering change. The technology level is evaluated from three aspects: the difficulty of resources supply, the maturity of technology and the advanced technology.

5. Security level: Production of complex products must be based on safety. Security factors are considered from two dimensions. The first is the safety of the manufacturing environment, for example improper operation may cause the engine explosion, local fire and other security risks. The second is the structural safety of product manufacturing guarantee. In summary, evaluate the change schemes from the manufacturing safety of the change project, the manufacturing safety of the change transmission project, and the safety degree of the overall structure safety. The safety of the 
change scheme is in accordance with the security system, staffing, emergency protection measures and other comprehensive assessment.

6. Environment level: Under the requirements of sustainable development and the increase of customer demand for green products, the environmental impact of product manufacturing changes involved can make a more reasonable assessment of the change scheme. Xiang[9] evaluated the green product from the perspective of the whole life cycle. Sun[10] researched on the evaluation of Green Product of Complex Products Based on pan-logic reasoning considering environmental coordination. These studies have played a supporting role in emphasizing the importance of environmental factors. This paper analyzes the material environmental protection, energy consumption and waste discharge based on environmental coordination. Material environmental protection refers to whether the material used in the change program conforms to the national testing standard. Energy consumption indicates fuel, electricity, and water expected to be consumed in the change scheme. Waste Disposal is comprehensively assess by he exclusion of harmful substances, it caused noise, dust, and other harmful substances by implementation of the surrounding environment.

According to the above six levels, it could further subdivide into 16 secondary indicators, the specific meaning is shown in Table 1.

Table. 1 The meaning of each evaluation index of complex product engineering change scheme

\begin{tabular}{|c|c|c|}
\hline \multirow{3}{*}{$\begin{array}{l}\text { Quality } \\
\text { level }\end{array}$} & $\begin{array}{l}\text { manufacturing quality of } \\
\text { change project }\end{array}$ & $\begin{array}{l}\text { Refers to the parts, materials and expected results which } \\
\text { change project used to meet the requirements. It is } \\
\text { based on the quality assurance system of the change } \\
\text { project, the quality control point setting, the staffing } \\
\text { situation and other comprehensive evaluation. }\end{array}$ \\
\hline & $\begin{array}{l}\text { manufacturing quality of } \\
\text { change propagating project }\end{array}$ & $\begin{array}{l}\text { Refers to the parts, materials and expected results which } \\
\text { change propagating project used to meet the } \\
\text { requirements, assessed on the same as above. }\end{array}$ \\
\hline & $\begin{array}{l}\text { manufacturing } \\
\text { quality of overall product }\end{array}$ & $\begin{array}{l}\text { Refers to the quality characteristics of the expected } \\
\text { product. It can be based on physical performance, } \\
\text { whether operation is reliable or not, the guarantee is } \\
\text { accurate or not, the appearance of aesthetically is } \\
\text { pleasing or not and other comprehensive assessment. }\end{array}$ \\
\hline \multirow{3}{*}{$\begin{array}{l}\text { Finance } \\
\text { level }\end{array}$} & Expected cost & $\begin{array}{l}\text { Including direct engineering costs, labor costs, indirect } \\
\text { fees, taxes and so on; }\end{array}$ \\
\hline & Expected return & Refers to the total price of the contract after the change \\
\hline & financial risk & $\begin{array}{l}\text { Refers to the probabilistic risk that may occur after } \\
\text { inflation, account arrears and financing difficulties. }\end{array}$ \\
\hline $\begin{array}{c}\text { Period } \\
\text { level }\end{array}$ & Total duration & $\begin{array}{c}\text { Refers to the length of time from the date of } \\
\text { manufacture of the contract to the expected delivery } \\
\text { date. }\end{array}$ \\
\hline \multirow{3}{*}{$\begin{array}{l}\text { Technology } \\
\text { level }\end{array}$} & Resource supply difficulty & $\begin{array}{l}\text { Refers to the extent to which the supply of resources to } \\
\text { meet the demand. It is determined from the material, } \\
\text { labor, power resources. }\end{array}$ \\
\hline & Technical maturity & $\begin{array}{l}\text { Refers to Development state which the technology used } \\
\text { by change relative to the engineering change project. }\end{array}$ \\
\hline & Technical advance & $\begin{array}{l}\text { Refers to the advanced level which the technology used } \\
\text { in change scheme compared to that used in the } \\
\text { pre-change scheme in terms of cost reduction, } \\
\text { performance improvement, energy efficiency and } \\
\text { emission reduction. }\end{array}$ \\
\hline \multirow{3}{*}{$\begin{array}{l}\text { Security } \\
\text { level }\end{array}$} & $\begin{array}{l}\text { manufacturing safety of } \\
\text { change project }\end{array}$ & $\begin{array}{l}\text { Refers to the security status of the project } \\
\text { manufacturing environment, according to the safety } \\
\text { assurance system, staffing, emergency protection } \\
\text { measures and other comprehensive assessment. }\end{array}$ \\
\hline & $\begin{array}{l}\text { manufacturing safety of } \\
\text { change propagating project }\end{array}$ & $\begin{array}{l}\text { Refers to the security status of the change propagating } \\
\text { project manufacturing environment, assessed on the } \\
\text { same as above. }\end{array}$ \\
\hline & Overall structural safety & $\begin{array}{l}\text { Refers to the affordable degree under possible loads, } \\
\text { storms, and non-load effects(temperature effects, }\end{array}$ \\
\hline
\end{tabular}




\begin{tabular}{c|c|c}
\hline \multirow{1}{*}{$\begin{array}{c}\text { Environmen } \\
\text { t level }\end{array}$} & $\begin{array}{c}\text { shrinkage and creep of structural materials, external } \\
\text { deformation, restrained deformation, environmental } \\
\text { erosion and corrosion) after complex product } \\
\text { manufacturing completed, That is, with sufficient } \\
\text { bearing capacity. }\end{array}$ \\
\cline { 2 - 3 } & Energy consumption & $\begin{array}{c}\text { Refers to whether the material used in the change } \\
\text { scheme conforms to the national testing standards. }\end{array}$ \\
\cline { 2 - 3 } & Waste discharge & $\begin{array}{c}\text { Refers to fuel, electricity, water and so on which is } \\
\text { expected to consume in change scheme. }\end{array}$ \\
\hline & $\begin{array}{c}\text { Refers to noise, dust and other harmful substances } \\
\text { emissions caused by the implementation of the project } \\
\text { on the surrounding environment. }\end{array}$ \\
\hline
\end{tabular}

\section{Conclusion}

This paper constructs the index system of complex product engineering change scheme evaluation with sixteen indicators of six levels sorted by literature. The evaluation of the scheme is to provide a quantitative basis and scientific decision-making basis for the multi-scheme optimization in the actual change manufacturing. Through the analysis of the six levels of quality, finance, period, technology, safety and environment, sixteen key indicators are filtered to evaluate the change scheme. The index system is to make up for statistical and quantitative imperfections in index system of the previous research, the second is to lay the theoretical basis for the evaluation of the complex product change schemes and multi-scheme optimization.

\section{Acknowledgment}

Funding: This research has been funded by National Science Foundation of China (No. 71471078), Humanities and Social Science Research Projects in Ministry of Education of China (No. 16YJA630056)

\section{References}

[1] Zhang G F, Liu Y J, Ji Z S. Simulation and optimization of ship segmentation construction scheme [J] .Computer Integrated Manufacturing System .2011, 17 (12): 2643-2651.

[2] Fang H, Tan J R, Yin G F. Design scheme of multi-attribute decision-making based on improved uncertain language [J] .Computer Integrated Manufacturing System, 2009, 15 (7): 1257-1261.

[3] Sa R N, Zhang G. Joint variable weight group decision making method for complex product design [J]. Journal of Zhejiang University (Engineering Science), 2013, 47 (4): 711-719.

[4] Zeitoun A A early warning signs of project changes[R]. Construction Industry Institute, Source Document.CII,Austin, Tex,1992,24

[5] Gong Z W, Mo R, Yang H C, et al. Engineering change based on product development network Hub node [J]. computer integrated manufacturing system, 2012, 18 (1): 40-46

[6] Simon H A. The sciences of the artificial [M]. ed., ed. Vol.: MIT press. 1996.

[7] Tian X G, Qiu Z M, Duan M Y. Progress risk analysis of naval gun weapon development based on multivariate risk probability model [J] Journal of China Ordnance 2008, 29 (5): 521-525.

[8] Qiu W G, Xu G Y, Xing J W. Stochastic network modeling and simulation analysis of schedule risk [J]. Journal of The Academy of Armored Forces Engineering, 2005, 19 (1): 48-51

[9] Duan G H, Wang J S, etc. Comprehensive evaluation of product greenness based on product system [J]. computer integrated manufacturing systems, 2001, 7 (8): 12-16. 
[10] Sun L F, Q L M, Zhang S Y, et al. Design scheme and evaluation technique for green analysis of complex product fusion based on universal logic reasoning [J]. computer integrated manufacturing systems, 2013, 19 (8): 1990-1999. 